\title{
Metatarsal metastasis as the presenting feature of occult colorectal carcinoma
}

\author{
Ruwan Wijayaratna, Joyce Wing Yin Ng
}

Faculty of Medicine, Nursing and Health Sciences, Monash University, Melbourne, Victoria, Australia

\section{Correspondence to}

Ruwan Wijayaratna, rc.wijayaratna@gmail.com
To cite: Wijayaratna $R$, Ng JWY. BMJ Case Rep Published online: [please include Day Month Year] doi:10.1136/bcr-2013010353

\section{DESCRIPTION}

A woman aged 88 years presented with a 12- month history of worsening pain in her left foot. On examination, a mass measuring $9 \mathrm{~cm}$ in the maximal dimension was seen in the medial aspect of the mid-foot, which was tender on palpation (figure 1). There was no other significant medical history and she was clinically well.

MRI of the foot showed a destructive lesion replacing the shaft and base of the left first metatarsal extending into adjacent bones and a smaller lesion in the posterior distal tibial metadiaphysis (figure 2). Biopsy of the metatarsal lesion demonstrated poorly differentiated carcinoma with cytokeratin 7 and estrogen receptor positivity, suggestive of metastatic breast cancer.

However, positron emission tomography scan showed no uptake in breast tissue and instead revealed moderate-to-intense uptake circumferentially in the wall of the rectosigmoid junction with four moderately avid mesorectal nodes (figure 3A). Uptake in multiple subcentimetre nodules in the lung was suggestive of metastatic disease (figure 3B). These findings were consistent with a primary colorectal cancer (CRC) with distant metastases to the lung and left foot.

Skeletal metastases occur in 30\% of malignancies and in $6.6 \%$ of patients with CRC. ${ }^{1}{ }^{2}$ However,
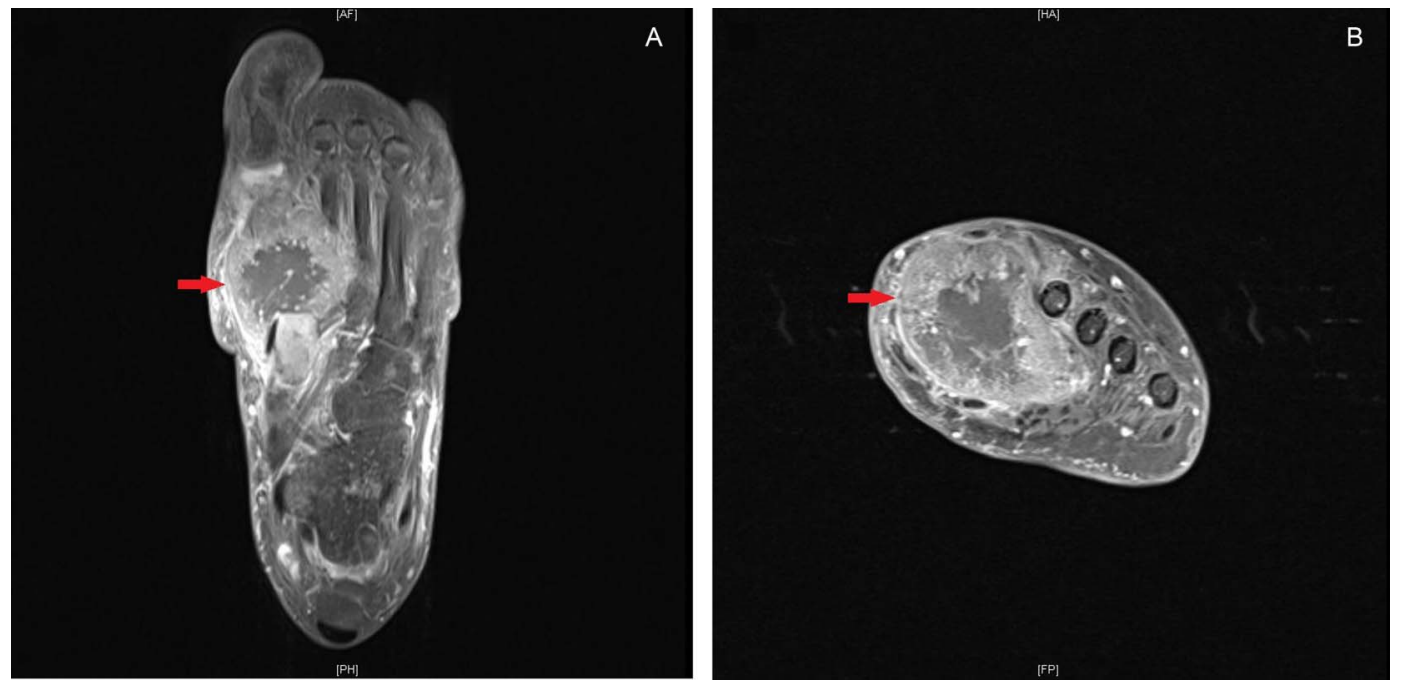

Figure 2 MRI of the left foot showing destructive $46 \times 45 \times 44 \mathrm{~mm}$ lesion replacing the base and shaft of the left great toe metatarsal with intra-articular extension plus extension into the adjacent bones proximally (red arrows).

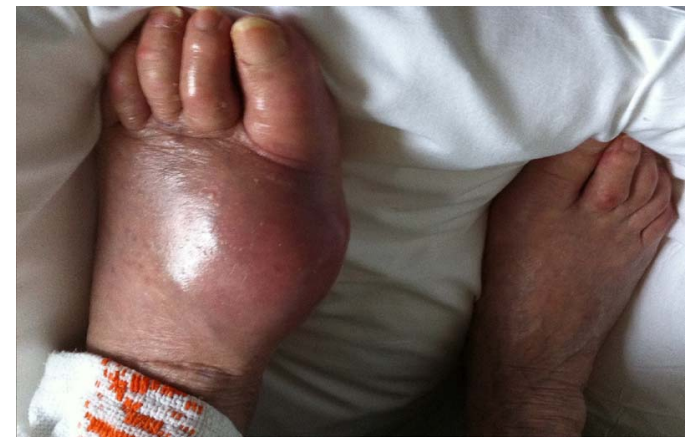

Figure 1 Photograph of the left foot demonstrating a mass (measuring $9 \mathrm{~cm}$ in the maximal dimension) on the medial aspect with overlying signs of inflammation over the dorsal aspect.

metastases to the hand and foot (acrometastasis) are rare in CRC and indeed in any malignancy with an occurrence rate of only $0.1 \% .^{1}$ Our case is unusual as it demonstrates a case of acrometastasis in metatarsal bone as a first presentation of CRC. A high index of suspicion for malignancy in this case enabled prompt diagnosis. Management was symptom-based and limited to radiotherapy to the foot. 


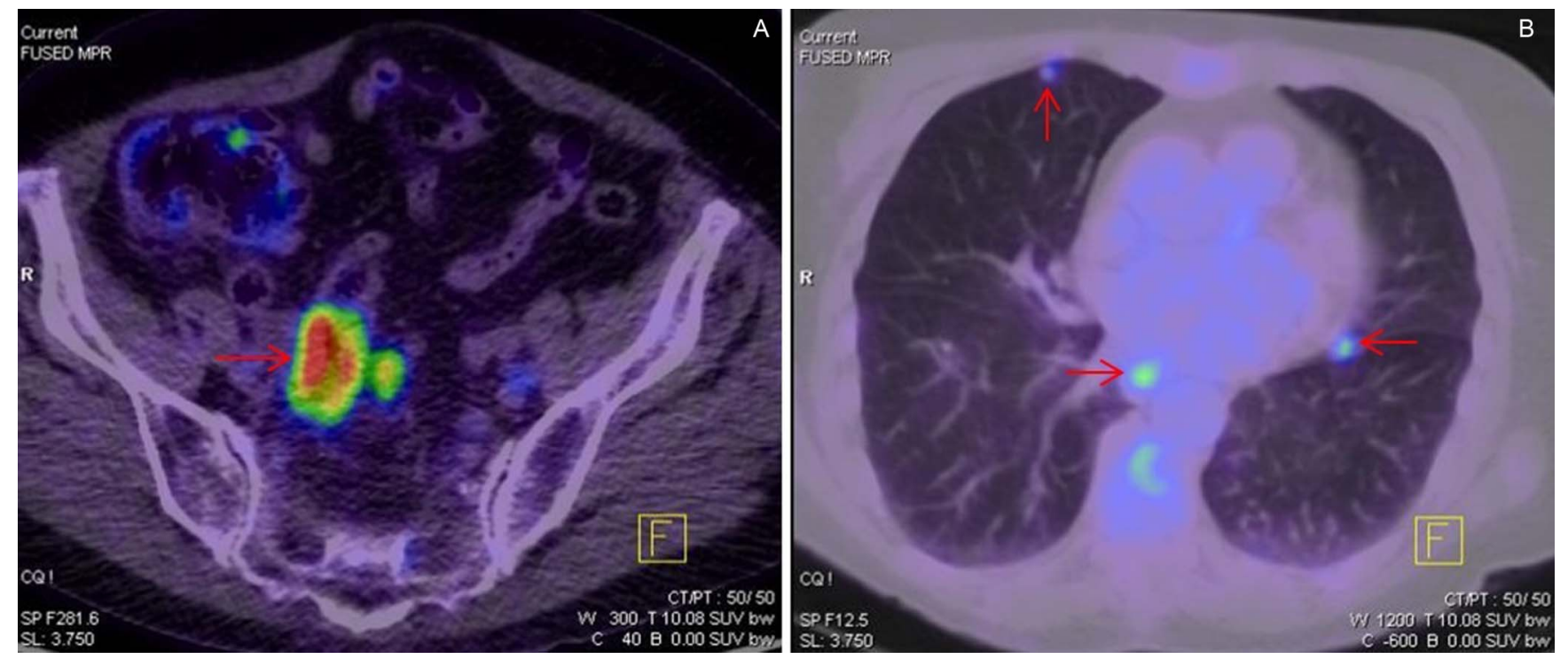

Figure 3 (A) Positron emission tomography (PET) scan demonstrating circumferentially increased uptake in the wall of the rectosigmoid junction and adjacent lymph node, consistent with a primary colorectal carcinoma. (B) PET scan showing multiple subcentimeter nodules with increased uptake across both lung fields suggestive of metastatic disease.

\section{Learning points}

- Acrometastasis is rare and occurs in only $0.1 \%$ of primary tumours. ${ }^{1}$

- A high degree of clinical suspicion for metastatic disease is needed in a patient presenting with chronic foot pain to allow for prompt diagnosis and treatment.

- During the evaluation of metastatic cancers of unknown origin, the presence of estrogen receptor positivity, though suggestive of breast cancers, need not always be from breast cancers.
Contributors RW and JWYN contributed to the conception and design, acquisition of the data and analysis, and interpretation of the data; drafting the article or revising it critically for important intellectual content and gave final approval of the version published.

Competing interests None.

Patient consent Obtained.

Provenance and peer review Not commissioned; externally peer reviewed.

\section{REFERENCES}

1 Ellington JK, Kneisl JS. Acrometastasis to the foot: three case reports with primary colon cancer. Foot Ankle Spec 2009;2:140-5.

2 Kanthan R, Loewy J, Kanthan SC. Skeletal metastases in colorectal carcinomas: a Saskatchewan profile. Dis Colon Rectum 1999:42:1592-7.

Acknowledgements The authors would like to thank Dr Chen Lee and Dr Peter Briggs.

Copyright 2013 BMJ Publishing Group. All rights reserved. For permission to reuse any of this content visit http://group.bmi.com/group/rights-licensing/permissions.

BMJ Case Report Fellows may re-use this article for personal use and teaching without any further permission.

Become a Fellow of BMJ Case Reports today and you can:

- Submit as many cases as you like

- Enjoy fast sympathetic peer review and rapid publication of accepted articles

- Access all the published articles

- Re-use any of the published material for personal use and teaching without further permission

For information on Institutional Fellowships contact consortiasales@bmjgroup.com

Visit casereports.bmj.com for more articles like this and to become a Fellow 